\title{
Hepatitis G virus (HGV): where we stand and what to do?
}

\section{Q. Mughis Uddin Ahmed}

Department of Pathology \& Laboratory Medicine (105),

King Abdulaziz Hospital (NGHA),

P.O. Box \#2477 Al-Ahsa-31982, Saudi Arabia

Fax: 0096635910000-34088

E-mail: drmughis@rediffmail.com

E-mail: ahmedMU2@ngha.med.sa

\begin{abstract}
Hepatitis G virus was identified in 1995. Some work was done on HGV until 1997 and the FDA declared it as a non-harmful virus. This resulted in no screening of virus for blood donors and bags from 1997 until today. A review of scientific literature of the last 16 years, majority identify with polymerase chain reaction (PCR) has shown that $\mathrm{HGV}$ is quite prevalent around the globe with low to high prevalence in different countries among blood donors and other groups. It was found to be associated in hepatitis, cirrhosis of the liver and possibly present in hepatocellular carcinoma. It was also seen in hematological disorders and hematological malignancies. It is advisable that screening of blood is better than transferring HGV ignorantly to blood recipients as it was done before, where we did transfer HCV to many individuals which resulted in a lot of morbidities and mortalities.
\end{abstract}

Keywords: hepatitis G virus; HGV; hepatitis; polymerase chain reaction; PCR.

Reference to this paper should be made as follows: Ahmed, Q.M.U. (2011) 'Hepatitis G virus (HGV): where we stand and what to do?', Int. J. Immunological Studies, Vol. 1, No. 3, pp.255-263.

Biographical notes: Q. Mughis Uddin Ahmed is currently working as a Consultant Microbiologist and Section Head at Microbiology and Serology (Immunology) Department of Pathology and Laboratory Medicine, King Abdulaziz Hospital (NGHA) Al-Ahsa Saudi Arabia. He has 31 years experience in his subject field. His highest post held was as a Professor, a Senior Consultant and the Head of Department of Pathology working as a Professor and a Senior Consultant from 1996-2009. He has presented 60 papers in national and international conferences and seminars and published 85 papers and written nine books. He is the founder editor of a journal and an editorial board member of four journals. He has received five awards including Service to Humanity (1993) and Pride of Performance from Karachi Metropolitean Corporation, Karachi-Pakistan (2001).

\section{Introduction}

Hepatotropic viral infections include hepatitis A virus (HAV), hepatitis B virus (HBV), hepatitis $\mathrm{C}$ virus (HCV), hepatitis D virus (HDV) and hepatitis E virus (HEV), all of 
which are quite prevalent in our population. Viral hepatitis has been known to us for more than 40 years. For example, HAV was discovered in 1973 and belongs to the Picornaviridae family. HBV was discovered earlier in 1970 and belongs to the Hepdnaviridae family. HCV was recognised in 1988 and belongs to the novel Flaviviridae family. HDV was identified in 1977 and belongs to the Deltaviridae family and HEV was discovered in 1985 belongs to the Calciviridae family. Hepatitis G virus (HGV) was identified in 1995 and belongs to the Flaviviridae family same as HCV, however, it is not a pure hepatotropic virus (Table 1) (Mujeeb, 1998; Chopra, 2010; Zuberi, 1996; Khokhar, 2002; Hamid et al., 2004; Taylor et al., 2000; Reshetiyak, 2008; Chang and Chen, 1999; Quer et al., 2003; Lai et al., 2004; Magder et al., 2005; Terrault, 2002; Marx et al., 2003; Rehman and Hafiz, 2000; Rafiq et al., 1999).

Table 1 Different types of hepatitis viruses

\begin{tabular}{|c|c|c|c|c|c|c|c|c|c|}
\hline Name & Genome & Genus & $\begin{array}{c}\text { Mode of } \\
\text { trans. }\end{array}$ & $\begin{array}{l}\text { Ag. in } \\
\text { blood }\end{array}$ & $\begin{array}{c}\text { Antibody } \\
\text { in blood }\end{array}$ & $\begin{array}{l}\text { Chronic } \\
\text { carrier }\end{array}$ & $\begin{array}{l}\text { Chronic } \\
\text { hepatitis/ } \\
\text { cirrhosis }\end{array}$ & $\begin{array}{l}\text { Liver } \\
\text { cancer }\end{array}$ & Envelope \\
\hline HAV & ssRNA & Picorna-virus & Orofecal & HA ag & Anti HA & No & No & No & No \\
\hline $\mathrm{HBV}$ & dsDNA & Hepdna-virus & $\begin{array}{l}\text { Blood, } \\
\text { sex, } \\
\text { placental }\end{array}$ & $\begin{array}{c}\text { HBs } \\
\text { Core } \\
\text { E-antigen }\end{array}$ & $\begin{array}{c}\text { Anti HBs } \\
\text { Anti-core } \\
\text { Anti-e }\end{array}$ & $5 \%-10 \%$ & $1 \%-5 \%$ & Yes & Yes \\
\hline $\mathrm{HCV}$ & ssRNA & Flavi-virus & $\begin{array}{l}\text { Blood, } \\
\text { sex, } \\
\text { placental }\end{array}$ & $\mathrm{HC}$ ag & Anti-HC & $50 \%$ & $20 \%$ & Yes & Yes \\
\hline HDV & ssRNA & Delta-virus & Blood & HD ag & Anti-HD & $>50 \%$ & $>50 \%$ & $?$ & Yes \\
\hline $\mathrm{HEV}$ & ssRNA & Calci-virus & Orofecal & $\mathrm{HE}$ ag & Anti-HE & No & No & No & No \\
\hline $\mathrm{HGV}$ & ssRNA & Flavi-virus & $\begin{array}{l}\text { Blood, } \\
\text { sex, } \\
\text { placental }\end{array}$ & HG ag & Anti-HG & $?$ & $?$ & $?$ & Yes \\
\hline
\end{tabular}

HAV is a single stranded RNA (ssRNA) virus without an envelope. The size of this virus is $27 \mathrm{~nm}$ and it belongs to Picornaviridae family. There are no chronic carrier states or chronic hepatitis/cirrhosis or cancer with HAV. In addition a vaccine is available for HAV (Mujeeb, 1998; Chopra, 2010; Zuberi, 1996; Khokhar, 2002; Hamid et al., 2004). The other virus transmitted by orofaecal route is HEV. HEV is also an ssRNA virus and is without an envelope. The size of the HEV virus is $30-37 \mathrm{~nm}$ and it belong to Calciviridae family. HEV infection is self-limiting and without any complications. However, deaths from this virus in pregnant women have been recorded (Mujeeb, 1998). $\mathrm{HBV}$ is transmitted by parenteral, perinatal and through sexual practices. HBV is the only DNA virus in hepatotropic viruses. HBV is a double stranded DNA (dsDNA) with a small portion of ssDNA. The size of virus is variable $(42 \mathrm{~nm})$ with an envelope and belongs to Hepdnaviridae family. HBV virus leads to chronic carrier state in $5 \%-10 \%$ of those infected and chronic hepatitis and cirrhosis in $1 \%-5 \%$. There is a definite association of HBV with liver cancer (Hepatocellular carcinoma) (Mujeeb, 1998; Chang and Chen, 1999; Quer et al., 2003; Lai et al., 2004; Magder et al., 2005; Terrault, 2002; Marx et al., 2003). HBV vaccine and immunoglobulins prevention and treatment modalities are available. HCV has both parenteral and sexual routes of transmission. This virus is ssRNA, 30-60 nm in size with an envelope and belongs to the Flaviviridae family. This virus can lead to chronic carrier states in $50 \%$ and chronic hepatitis and 
cirrhosis in $20 \%$ of those infected. It has been associated with liver cancer (hepatocellular carcinoma). HBV and HCV are the most likely causes of viral hepatitis in Pakistan (Mujeeb, 1998; Chopra, 2010; Khokhar, 2002; Taylor et al., 2000). There is no vaccine available in the market against HCV (Rehman and Hafiz, 2000; Rafiq et al., 1999; Mibagheri, 1999; Ahmed et al., 2006, 2008; Oliveira et al., 2002; Kumar et al., 2007; Alter et al., 1997a, 1997b; Martinol et al., 1997a; Alter, 1996; Odeh et al., 2005; Ling et al., 1997; Simon et al., 1995; Moaven et al., 1998; Ather, 1997; Ramla and Al-Falehh, 1999; Praharaj et al., 2005; Xu et al., 2001; Forns et al., 1997; Noh et al., 1998; Hammad and Zaghloul, 2009; Nogueira et al., 2001; Tanka et al., 1998; Linnen et al., 1996; Tanaka et al., 1996a). HDV is a defective virus which needs the envelope of HBV to overcome its defect. HDV is ssRNA virus, $25 \mathrm{~nm}$ in size with an envelope and belongs to Deltaviridae family. This virus can lead to chronic carrier states in $50 \%$ and chronic hepatitis and cirrhosis in 50\% (Rehman and Hafiz, 2000). Two newly identified viruses in Japan are TT Virus circular ssDNA, naked with 40 Genotypes belongs to Circoviridae identified 1997, second is the SEN virus observed in Italy for the first time in 2000 and belongs to genus similar to TT virus with eight genotypes (Ahmed et al., 2006, 2008).

\section{Different results and discussion on global studies}

HGV was first identified about 15 years ago. A lot of work has been done throughout the world on this virus. However, very little work is being done in Pakistan. The clinical course of acute and chronic viral hepatitis has not been studied at length. HGV is transmitted as conventional blood borne pathogens. This virus is composed of ssRNA, size $30-60 \mathrm{~nm}$ with an envelope and belongs to novel family of Flaviviridae same as $\mathrm{HCV}$ with $29 \%$ amino acids less in HGV. Other names of this virus are accidental tourist virus/human orphan flavivirus/innocent bystander virus. Interestingly HGV was isolated from blood of blood donors. It is quite prevalent amongst intravenous drug users. There are several modes of transmission for HGV by blood and blood products. It has sexual mode of transmission. It is transmitted from infected mothers to their fetuses. It can also be transmitted to hemophilia patients using factor VIII, parenteral drug users, peritoneal dialysis, hemodialysis and organ transplantation. This virus can lead to acute or chronic liver disease alone or it may co-exist as dual or triple infection (HGV and HCV or HGV, HCV and HBV) (Rafiq et al., 1999; Mibagheri, 1999; Ahmed et al., 2006, 2008; Oliveira et al., 2002; Kumar et al., 2007; Alter et al., 1997a, 1997c). HGV has five genotypes. Genotype 1 is present in West Africa. Genotype 2 is present in North and South America, Europe, East Africa and Subcontinents (Pakistan and India). Genotype 3 is present in China and other Asian Countries. Genotype 4 is present in Myanmar and Vietnam and Genotype 5 is present in South Africa (Reshetiyak, 2008; Ahmed et al., 2006, 2008; Oliveira et al., 2002; Kumar et al., 2007; Alter et al., 1997a). HGV status from different studies ranged from a low prevalence of $0.9 \%-5.7 \%$, to a medium prevalence of $5.8 \%-9.9 \%$. For high prevalence the range is $10 \%-20 \%$ and for very high prevalence it is above $20 \%$. Possible mode of transmission is blood and blood products transfusion (s) 0.5-20.0 haemophiliacs $48.0 \%$, sexual transmission (11.0\%-21\%), intravenous drugs users $(13.5 \%)$, haemodialysis $(26.5 \%)$, peritoneal dialysis $(13.6 \%)$, organ transplants ( $25.0 \%$ in liver transplant) and vertical transmission (12.5\% to $33.3 \%$ ). Clinical signs and symptoms although asymptomatic in the majority of cases, may include fatigue, jaundice, abdominal pain, nausea, diarrhea and loss of appetite. The incubation period of HGV has 
yet to be determined. Prevalence of $\mathrm{HGV}$ infection ranges from $0.5 \%-20.0 \%$ for example, It is $4.0 \%$ in Australia (1996), Brazil 4.4\% (2001) and 7.1\% (2002) now $4.4 \%-10.0 \%$, Colombia 6.1\% (1998), India 2.3\% (2005) and 6.0\% (2007), Iran 5.5\% (2003) and 4.8\% (2009), Hungary 5.5\% (1999), Japan 5.0\% (2005), Pakistan 0.5\%-2.3\% (1999), Africa $10.0 \%-20.0 \%(1996,1997$ and 1998) and USA 1.6\% (1996), although it is now $1.2 \%-2.0 \%$. Further it has been observed that HGV infection was $11.3 \%$ in patients with HIV infection. HGV infection with HIV was $11.0 \%$ in other study. In another study, in Tanzania HGV with HIV infection was 23.0\% (Rafiq et al., 1999; Mibagheri, 1999; Ahmed et al., 2006, 2008; Oliveira et al., 2002; Kumar et al., 2007; Alter et al., 1997a, 1997b; Martinol et al., 1997a; Alter, 1996; Odeh et al., 2005; Ling et al., 1997; Simon et al., 1995; Moaven et al., 1998; Ather, 1997; Ramla and Al-Falehh, 1999; Praharaj et al., 2005; Xu et al., 2001; Forns et al., 1997; Noh et al., 1998; Hammad and Zaghloul, 2009; Nogueira et al., 2001; Tanka et al., 1998; Linnen et al., 1996; Tanaka et al., 1996a; Stapleton et al., 2004; Xu et al., 2001; Ren et al., 2005; Singh, 2002; Anthony, 2000; Lampe et al., 1998; Yang et al., 2006). In our study HGV was 1.3\% amongst total blood donors. In professional donors it was high $2.3 \%$ and in volunteer donors it was much less $0.5 \%$. The highest number of positive for HGV in the total group was $3.3 \%$ in $50-59$ years age. The group of professional donors aged $50-59$ years age group, it was $6.7 \%$. In volunteer donors aged $40-49$ years of age it was $2.2 \%$. HGV infection is an emerging infection that needs more research and liver function monitoring for longer periods before predicting its outcome (Ahmed et al., 2006, 2008). HGV in Intra venous drugs users (IDUS) is $13.5 \%$. HGV infection was detected in alcoholics at $56.0 \%$. Parenteral drug users also acquired HGV infection. The methods of transmission mentioned earlier are all possible modes with HGV. Although, there is no vaccine currently available, response to alpha interferon therapy was seen in some studies. Further viremia persists for years and it is five times more than HCV. The standard method of diagnosis is use of polymerase chain reaction (PCR). Although, HGV appears to benefit HIV positive patients, it can not be declared as innocent virus (Rafiq et al., 1999; Mibagheri, 1999; Ahmed et al., 2006, 2008; Stark et al., 1996).

In a study fulminant hepatitis with $\mathrm{HGV}$ was seen in $16.7 \%$ and acute viral hepatitis in $10.0 \%$ of cases. HGV alone was present in hepatitis cases at a rate of $33.8 \%(52 / 154)$ with other viruses $66.2 \%(102 / 154)$ in a study. Chronic Hepatitis was up to $9.8 \%$ as compared to $21 \% \mathrm{HBV}$ in another study. In a study done at other centre it was observed that HGV infection in $75 \%$ of cases has presented with normal LFT. HGV in chronic liver diseases was from $3.5 \%$ to $8.3 \%$ in a study done at Singapore. In another study it was found that HGV infection biopsies showed similar changes seen in HCV. Further in Japan $50 \%$ of HGV infections were acute fulminant hepatitis. While in the USA. Acute viral hepatitis with $\mathrm{HGV}$ was $0.3 \%$ and it was positive in $20.0 \%$ of cryptogenic cirrhosis. On the contrary HGV infection was detected $89.0 \%$ in cirrhotic patients. HGV was detected in $10.0 \%$ cases of autoimmune hepatitis or alcoholic hepatitis. In another study it has been reported that HGV-RNA in patients with hepatocellular carcinoma was around $6.0 \%$. Recent studies suggest that $88 \%$ hepatocellular carcinoma cases had cirrhosis which was related to presence of $\mathrm{HBV}(62.0 \%)$, HCV (38.0\%) and $\mathrm{HGV}(28.0 \%)$. However, isolated HGV infection was detected in only $3.0 \%$ cases. HGV infection among Brazilian patients with chronic liver disease and blood donors were also seen. Prospective evaluation of infection with HGV in relation to hepatocellular carcinoma is under study in Shanghai, China (Reshetiyak, 2008; Chang and Chen, 1999; Stark et al., 
1996; Yuan et al., 2000; Tagger et al., 1997; Kanda et al., 1997; Xuezhong et al., 2000; Leao-Filho et al., 2007). Hepatitis GB virus-C RNA has been detected from Japanese patients with hepatocellular carcinoma and cirrhosis. In chronic hepatitis prevalence and clinical significance is very important in assessing future outcome of such infections. $\mathrm{HGV}$ viremia persist for years in such patients as compared with $\mathrm{HCV}$ and it is five times more in quantity. HGV has also been present in patients with autoimmune hepatitis and alcoholic hepatitis besides already mentioned clinical identities/diseases. Macaca mulatta monkey type now can be used as animal model for future research and studies on the HGV (Ren et al., 2005; Martinol et al., 1997b; Adrian and Bisceglie, 1996; Tanaka et al., 1996b; Stark et al., 1996; Yuan et al., 2000; Tagger et al., 1997; Kanda et al., 1997; Xuezhong et al., 2000; Leao-Filho et al., 2007). HGV has been incriminated also in different hematological disorders. Further $\mathrm{HGV}$ in Haemophilia patients is $48 \%$. Additionally $\mathrm{HGV}$ in haematological diseases of different Malignant potential, such as Hodgkin's lymphoma, non-Hodgkin's lymphoma, acute leukaemia, myeloid-dysplasia, myelo-proliferative disease, multiple myeloma, thrombocytopenia, aplastic anaemia and leucopoenia. HGV infection in Hodgkin's disease was 8.0\% (HCV 9.0\%). Hepatitis G virus (GBV-C) is primarily a lymphotropic virus. Myeloiddysplasia, myeloproliferative disease, multiple myeloma, thrombocytopenia, aplastic anaemia, haemophilia and leukopenia also positive for HGV. HGV is also seen in malignant potential Hodgkin's lymphoma, non-Hodgkin's lymphoma, acute leukaemia. It was also seen in malignant potential Hodgkin's lymphoma, non-Hodgkin's lymphoma, acute leukaemia (Anthony, 2000; Tucker et al., 2000; Reshetiyak et al., 2008; Pavlova et al., 1999; Idilman et al., 2000; Keresztes et al., 2003).

\section{Conclusions}

The findings from the subject of studies done on HGV infection in different parts of the world can be found in patients with hepatocellular carcinoma, other malignancies such as acute, chronic fulminant hepatitis, cirrhosis of the liver and in other morbidities can contribute to this. It is advisable to recommend HGV testing become mandatory for each blood bag prior to transfusion. In the interest of safety, it is better that each blood bag be screened for $\mathrm{HGV}$ rather than risk transferring $\mathrm{HGV}$ to blood recipients. Although it will increase cost incurred on each blood bag, patient safety standards and safeguards must be the priority. The lesson learned from our past experiences must be heeded. In right condition of the latest evidence-based research outcomes, we follow old recommendations from FDA or reexamine our practices in light of recent studies.

\section{Recommendation}

Multi-centre studies for $\mathrm{HGV}$ in patients with acute and chronic hepatitis, fulminant hepatitis, cirrhosis and hepatocellular carcinoma and other malignancies should be done at different centres around the globe. It should be done with the support of national and international donor agencies to ascertain our position on the efficiency of HGV blood bags screening. 


\section{References}

Adrian, M. and Bisceglie, D. (1996) 'Hepatitis G virus infection: a work in progress', Ann Intern Med., Vol. 125, pp.772-773.

Ahmed, M.U., Ahmed, M., Ahmed, T. and Rehana, M. (2008) 'Is hepatitis G virus (HGV) screening necessary for each blood bag', Ann. Abbasi Shaheed Hosp. Karachi Med. Dent. Coll., Vol. 13, No. 1, pp.65-68.

Ahmed, M.U., Uddin, M., Ahmed, I., Ahmed, M. and Moin, A.A. (2006) 'Prevalence of hepatitis G virus (HGV) amongs blood donors in our population', Ann. Abbasi Shaheed Hosp. Karachi Med. Dent. Coll., Vol. 11, No. 1, pp.815-820.

Alter, H.J. (1996) 'The cloning and clinical implication of HGV and HGBV-C', N. Engl J Med., Vol. 334, pp.1536-1537.

Alter, H.J., Nakatsuji, Y., Melpolder, J., Wages, J., Wesley, R., Shil, J.W-K. and Kim, J.P. (1997a) 'The incidence of transfusion-associated hepatitis $G$ virus infection and its relation to liver disease', $N$ Engl J Med, Vol. 336, pp.747-754.

Alter, H.J., Nakatsuji, Y., Melpolder, J., Wages, J., Wesley, R., Shil, J.W-K. and Kim, J.P. (1997b) 'The incidence of transfusion-associated hepatitis $G$ virus infection and its relation to liver disease', $N$ Engl J Med., Vol. 336, pp.747-754.

Alter, M.J., Gallagher, M., Morris, T.T., Moyer, L.A., Meeks, E.L., Krawczynski, K., Kim, J.P. and Margolis, H.S. (1997c) 'Acute non-A-E hepatitis in the United States and the role of hepatitis G virus infection', $N$ Engl $J$ Med, (for the sentinel counties viral hepatitis study team), Vol. 336, pp.741-746.

Anthony, Y. (2000) 'Prevalence of hepatitis G virus in patients with hemophilia and their steady female sexual partners', Sexually Transmitted Diseases, March, Vol. 27, No. 3, pp.178-182.

Ather, H.J. (1997) 'G-pers creepers, where did you get those papers? A re-assessment of the literature on the hepatitis G virus', Transfusion, Vol. 7, pp.569-572.

Chang, M.H. and Chen, D.S. (1999) 'Prospectus of hepatitis B virus eradication and control of hepatocellular carcinoma', Clin Gastroenterol, Vol. 13, No. 4, pp.511-517.

Chopra, S. (2010) 'GB virus (hepatitis G) infection', available at http://www.update.com (accessed on 18 January).

Forns, X., Llama, F., Costa, J., Lopez-Labrador, F.X., Ampurdanes, S., Olemedo, E., Saiz, J.C., Guilera, M., Lopez-Pedret, J., Sanchez-Tapias, J.M., Darnell, A., Jimenez de Anta, M.T., Ordinas, A. and Rodes, J. (1997) 'Hepatitis G virus infection in a haemodialysis unit: prevalence and clinical implications', Vol. 12, pp.956-960.

Hamid, S., Umar, M., Alam, A., Siddiqui, A., Qureshi, H., Butt, J. and members of the consensus panel (2004) 'PSG consensus statement on management of hepatitis C virus infection', J. Pak. Med. Assoc., Vol. 54, pp.146-150.

Hammad, A.M. and Zaghloul, M.H.E. (2009) 'Hepatitis G virus in Egyptian children with chronic renal failure', Annals Clinical Microbiology \& Antimicrobials, Vol. 8, pp.36-42.

Idilman, R., Ustun, C., Aslan, O., Ozcan, M., Arat, M., Bozkaya, H., Bozdayi, M., Sengezer, T., Uzunalimoglu, O., Dokmeci, A., Ilhan, O., Koc, H. and Akan, H. (2000) 'The incidence of hepatitis $\mathrm{G}$ virus in patients with hematological malignancies: the relationship to number of blood and blood product transfusion', Turk J. Haematol, Vol. 17, No. 2, pp.67-71.

Kanda, T., Yokosuka, O., Imazeki, F., Tagawa, M., Ehata, T., Saisho, H. et al. (1997) 'GB virus-C RNA in Japanese patients with hepatocellular carcinoma \& cirrhosis', J. Hepatol., Vol. 27, p.464.

Keresztes, K., Takacs, M., Horanyi, M., Miltenyi, Z. and Illes, A. (2003) 'HCV and HGV infection in Hodgkin's disease', Pathology Oncology Research, Vol. 9, No. 4, pp.222-225.

Khokhar, N. (2002) 'Spectrum of chronic liver disease in a tertiary care hospital', J Pak Med Assoc, Vol. 52, pp.56-58. 
Kumar, D., Gupta, R.K., Anand, R., Pasha, S.T., Rai, A., Das, B.C. and Kar, P. (2007) 'Occurrence \& nucleotide sequence analysis of hepatitis $G$ virus in patients with acute viral hepatitis \& fulminant hepatitis', Indian J. Med. Res., June, Vol. 125, pp.752-755.

Lai, K.W., Young, K.C., Cheng, P.N., Chen, S.H. and Chang, T.T. (2004) 'Interspousal transmission of hepatitis $\mathrm{C}$ virus: application of comparing the variability of HVR1 nucleotide region', Hepatogastroenterology, Vol. 51, pp.791-795.

Lampe, E., de Oliveira, J.M., Pereira, J.L., Saback, F.L., Yoshida, C.F. and Neil, C. (1998) 'HGV infection among Brazilian patients with chronic liver disease \& blood donars', Clin. Diagn. Virol., Vol. 9, p.75.

Leao-Filho, G.C., Lopes, E.P.A., Ferraz, A.A.B., Moura, I., Pernambuco, J.R., Reis, C., Silva, A.E.B. and Ferraz, M.C.G. (2007) 'Hepatitis G virus infection in patients with hepatocellular carcinoma in Recife, Brazil', Jpn. J. Clin. Oncol., Vol. 37, No. 8, pp.632-636.

Ling, C.H., Mei-Hwei, C., Yen-Hsuan, N., Hong-Yuan, H., Jia-Horng, K. and Pei-Jer, C. (1997) 'Hepatitis G virus infection in normal and prospectively followed post transfusion children', Pediatric Research, Vol. 42, No. 6, pp.784-787.

Linnen, J., Wages, J., Jr., Zhang-Keck, Z., Fry, K.E., Krawcynski, K.Z. and Alter, H. (1996) 'Molecular cloning and disease association of hepatitis $G$ virus: a transfusion-transmissible agent', Science, Vol. 271, pp.505-509.

Magder, L.S., Fix, A.D., Mikhail, N.N., Mohammad, M.K., Abdel Hamid, M., Abdel Aziz, F. et al. (2005) 'Estimation of the risk of transmission of hepatitis C between spouses in Egypt based on seroprevalence data', Int J Epidemiol, Vol. 34, pp.160-165.

Martinol, M., Marcellin, P., Boyer, H., Detmer, J., Poutean, M. and Castelnau, C. (1997) 'Influence of hepatitis G virus infection on the severity disease', Intern. Med., Vol. 126, pp.874-881.

Martinol, M., Marcellin, P., Boyer, H., Detmer, J., Poutean, M. and Castelnau, C. (1997) 'Influence of hepatitis $\mathrm{G}$ virus infection on the severity disease', Intern. Med., Vol. 126, pp.874-881.

Marx, M.A., Murugavel, K.G., Tarwater, P.M., SriKrishnan, A.K., Thomas, D.L., Soloman, S. et al. (2003) 'Absence of hepatitis C virus infection with sexual exposure in southern India', Clin. Infect. Dis., Vol. 37, pp.514-520.

Mibagheri, S.A. (1999) 'Hepatitis G virus: a newly diagnosed infectious agent', Med. J., Vol. 1, No. 2, pp.60-62, Iran Hosp., Dubai.

Moaven, L.D., Hyland, C.A., Young, I.F., Bowden, D.S., McCaw, R., Mison, L. and Locarnini, S.A. (1998) 'Prevalence of hepatitis G virus in Queensland blood donors', MJA, Vol. 169, pp.373-374.

Mujeeb, S.A. (1998) 'Seroprevalence and pattern of viral hepatitis in Pakistan', J. Infect. Dis., Vol. 5, pp.19-20.

Nogueira, C.A.V., Nogueira, S.A., Nogueira, C.M., Coelho, H.S.M., Ketema, F., Edelman, D.C., Lambert, J.S. and Constantine, N.T. (2001) 'The incidence of GB virus C/hepatitis G virus infection in Brazilian patients who received blood transfusion during cardiac surgery', Journal of Medical Virology, Vol. 63, pp.237-241.

Noh, H., Kang, S.W., Choi, S.H., Shin, S.K., Seo, B.J., Lee, I.H., Choi, K.H., Han, D.S., Kim, H.S. and Lee, H.Y. (1998) 'Hepatitis G virus infection in hemodialysis and continuous ambulatory peritoneal dialysis patients', Yonsei Medical Journal, Vol. 39, No. 2, pp.110-121.

Odeh, R.O., Al-Moslih, M.I., Al-Jokhdar, M.W. and Ezzeddine, S.A. (2005) 'Detection and genotyping of GBC-C virus in United Arab Emirates', Journal of Medical Virology, Vol. 76, pp.534-540.

Oliveira, L.A., Martins, R.M.B., Carneiro, M.A.S., Teles, S.A., Silva, S.A., Cardoso, D.D.P., Lampe, E. and Yoshida, C.F.T. (2002) 'Prevalence and genotypes of GB virus C/hepatitis G virus among blood donors in central Brazil', Mem Inst Oswaldo Cruz, Rio de Janeiro, Vol. 97, pp.1-5.

Pavlova, B.G., Heinz, R., Selim, U., Tuchler, H., Pittermann, E. and Eder, G. (1999) 'Association of $\mathrm{GB}$ virus $\mathrm{C}(\mathrm{GBV}-\mathrm{C})$ /hepatitis $\mathrm{G}$ virus (HGV) with haematological diseases of different malignant potential', J. Med. Virol., Vol. 57, pp.361-366. 
Praharaj, A.K., Tripathy, L.C.S., Kalghatgi, C.A.K. and Nagendra, B.A. (2005) 'Hepatitis G virus: prevalence in blood donors in armed forces', MJAFI, Vol. 61, pp.333-335.

Quer, J., Murillo, P., Esteban, J., Martell, M., Esteban, R. and Guardia, J. (2003) 'Sexual transmission of hepatitis $\mathrm{C}$ virus from a patient with chronic disease to his sex partner after removal of an intrauterine device', Sex Transm. Dis., Vol. 30, pp.470-471.

Rafiq, M., Isomura, S., Yamamoto, N., Morishita, T., Sato, K., Rasool, A. et al. (1999) 'Prevalence of Hepatitis G RNA and associated HBs Ag. HCV-Abs. Viral markers among professional blood donors/drug addicts in Pakistan', JCPSP, Vol. 9, No. 10, pp.450-452.

Ramla, S. and Al-Falehh, F.Z. (1999) 'Review article hepatitis G virus (HGV) and liver disease', Saudi Journal of Gastroen., Vol. 5, No. 2, pp.50-55.

Rehman, S. and Hafiz, A. (2000) 'Study of HDV in high-risk population of hepatitis B', JCPSP, Vol. 10, No. 1, pp.29-32.

Ren, F.U., Zhu, F.L., Cao, M.M., Wen, X.Y., Zhao, P. and Qi, Z.T. (2005) 'Hepatitis G virus genomic RNA is pathogenic to Macaca multata', World J. Gastroenterol., Vol. 11, No. 7, pp.547-550.

Reshetiyak, V.I. (2008) 'Hepatitis G virus is a lymphotrophic virus', World J. Gastroenterol, Vol. 14, No. 30, pp.4725-4734.

Reshetiyak, V.I., Karlovich, T.I. and Ilchenko, L.U. (2008) 'Hepatitis G virus is a lymphotrophic virus', World J. Gastroenterol., Vol. 14, No. 30, pp.4725-4734.

Simon, J.N., Piolot-Matias, T.J., Leary, T.P., Sawson, G.J., Desal, S.M. and Schlander, G.G. (1995) 'Identification of two flavi virus-like genomes in the GB hepatitis agent', Proc. Natl. Acad. Sci. USA, Vol. 92, pp.3401-3405.

Singh, I. (2002) 'The ABCs of viral hepatitis diagnosis', Clin Path/Lab Med., Vol. 14, p.453.

Stapleton, J.T., Williams, C.F. and Xiang, J. (2004) 'GB virus type C, a beneficial infection?, J.Clin.icrobiol., Vol. 42, No. 9, pp.3915-3919.

Stark, K., Bienzle, U., Hess, G., Engel, A.M., Hegenscheid, B. and Schluter, V. (1996) 'Detection of the hepatitis $\mathrm{G}$ virus genome among injecting drug users, homosexual and bisexual men and blood donors', J. Infect. Dis., Vol. 174, pp.1320-1323.

Tagger, A., Donato, F., Ribero, M.L., Chiesa, R., Portera, G., et al. (1997) 'A case-control study on HGV infection \& hepatocellular carcinoma was done', Hepatology, Vol. 26, p.1653.

Tanaka, E., Mizokami, M., Orito, E., Ohba, K.I., Nakano, T., Kato, T., Kondo, Y., Ding, X., Ueda, R., Sonoda, S., Tajima, K., Miura, T. and Hayami, M. (1996) 'Effect of hepatitis G virus infection on chronic hepatitis C', Ann Intern Med, Vol. 125, pp.740-743.

Tanaka, E., Nakatsuji, Y., Shih, J.W., Kiyosawa, K., Wages, J. Jr., Kim, J.P. and Alter, H.J. (1996) 'Prevalence and disease association of hepatitis G virus infection in Japan', J. Viral Hepat., Vol. 3, pp.307-316.

Tanka, Y., Mizokami, M., Orito, E., Ohba, K.I., Nakano, T., Kato, T., Kondo, Y., Ding, X., Ueda, R., Sonoda, S., Tajima, K., Miura, T. and Hayami, M. (1998) 'GB virus C/hepatitis G virus infection among Colombian native Indians', Am. J. Trop. Med. Hyg., Vol. 59, No. 3, pp.462-467.

Taylor, V.M., Jackson, J.C., Pineda, M., Pham, P., Fischer, M. and Yasui, Y. (2000) 'Hepatitis B knowledge among Vietnamese immigrants: implications for prevention of hepatocellular carcinoma', J. Cancer Educ., Vol. 15, No. 1, pp.51-55.

Terrault, N. (2002) 'Sexual activity as a risk factor for hepatitis C', Hepatology, Vol. 36, S99-105.

Tucker, T.J., Smuts, H.E.M., Eedes, C., Knobel, G.D., Eickhaus, P., Robson, S.C. and Kirsch, R.E. (2000) 'Evidence that the GBV-C/hepatitis G virus is primarily a lymphotropic virus', Journal of Medical Virology, Vol. 61, pp.52-58.

Xu, J.Z., Yang, Z.G., Le, M.Z., Wang, M.R., He, C.L. and Sui, Y.H. (2001) 'A study on pathogenicity of hepatitis G virus', World J Gastrenterol., Vol. 7, No. 4, pp.547-550.

Xu, J.Z., Yang, Z.G., Le, M.Z., Wang, M.R., He, C.L. and Sui, Y.H. (2001) 'A study on pathogenicity of hepatitis G virus', World J Gastroenterol., Vol. 7, No. 4, pp.547-550. 
Xuezhong, L., Naitoh, S., Xuewen, D., Zhao, L. and Akahana, Y. (2000) 'GB virus C/hepatitis G virus infection with hepatocellular carcinoma', Hepatol Res., Vol. 16, p.91.

Yang, J.F., Dai, C.Y., Chuang, W.L., Lin, Z.Y., Chen, S.C., Lin, W.Y., Lin, Z.Y., Chen, S.C., Hsieh, M.Y., Wang, L.Y., Tsai, J.F., Chang, W.Y. and Yu, M.L. (2006) 'Prevalence \& clinical significance of HGV/HBV-C in patients with chronic hepatitis B or C', Jpn. Infect. Dis., Vol. 59, p.25.

Yuan, J.M., Govindarajan, S., Goa, Y.T., Ross, R.K. and Yu, M.C. (2000) 'Prospective evaluation of infection with HGV in relation to hepatocellular carcinoma in Shanghai, China', J. Infect. Dis., Vol. 182, p.1300.

Zuberi, S.J. (1996) 'Seroepidemiology of HBV and HCV in Pakistan', Int. J. Hepatol, Vol. 5, pp.19-26. 